\title{
Monoassociation with Lactobacillus acidophilus U FV-H 2b20 stimulates the immune defense mechanisms of germfree mice
}

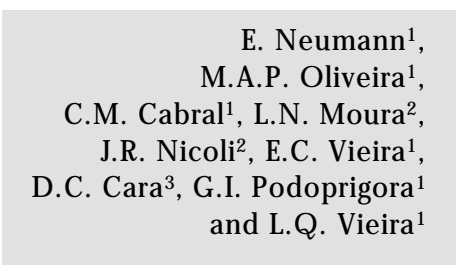

\author{
Departamentos de 1Bioquímica e Imunologia, $2 \mathrm{M}$ icrobiologia, and \\ 3Patologia Geral, Instituto de Ciências Biológicas, \\ Universidade Federal de M inas Gerais, Belo Horizonte, MG, Brasil
}

\section{Correspondence \\ L.Q. Vieira \\ Departamento de Bioquímica e \\ Imunologia, ICB, UFM G \\ Caixa Postal 486 \\ 30161-970 Belo Horizonte, MG \\ Brasil \\ E-mail: Iqvieira@ icb.ufmg.br \\ Resarch supported by CN Pq (No. 8.30186/97-2) and CAPES (PRO AP/Taxa acadêmica). E. Neumann is the recipient of a CAPES fellowship, C.M. Cabral is the recipient of a PIBIC/CN Pq fellowship, J.R. Nicoli, E.C. Vieira and L.Q. Vieira are recipients of CN Pq fellowships. G.I. Podoprigora is the recipient of fellowships from CNPq (No. 520100/95.6) and FAPEMIG (No. CBS 915/95). Part of a Ph.D. thesis presented by E. Neumann to the Departamento de Bioquímica e Imunologia, ICB, Universidade Federal de Minas Gerais, Belo Horizonte, MG, Brasil.}

Received January 29, 1998 Accepted August 25, 1998

\section{Abstract}

Probiotics are formulations containing live microorganisms or microbial stimulants that have some beneficial influence on the maintenance of a balanced intestinal microbiota and on the resistance to infections. The search for probiotics to be used in prevention or treatment of enteric infections, as an alternative to antibiotic therapy, has gained significant impulse in the last few years. Several studies have demonstrated the beneficial effects of lactic acid bacteria in controlling infection by intestinal pathogens and in boosting the host's nonspecific immune response. Here, we studied the use of Lactobacillus acidophilus UFV-H2b20, a lactic acid bacterium isolated from a human newborn from Viçosa, Minas Gerais, Brazil, as a probiotic. A suspension containing $10^{8}$ cells of Lactobacillus acidophilus UFV-H2b20 was inoculated into groups of at least five conventional and germfree Swiss mice to determine its capacity to stimulate the host mononuclear phagocytic activity. We demonstrate that this strain can survive the stressing conditions of the intestinal tract in vivo. Moreover, the monoassociation of germfree mice with this strain for seven days improved the host's macrophage phagocytic capacity, as demonstrated by the clearance of a Gram-negative bacterium inoculated intravenously. Monoassociated mice showed an undetectable number of circulating $E$. coli, while $0.1 \%$ of the original inoculum was still present in germfree animals. Mice treated with viable or heat-killed Lactobacillus acidophilus UFV-H2b20 presented similarly improved clearance capacity when compared with germfree controls. In addition, monoassociated mice had twice the amount of Kupffer cells, which are responsible for the clearance of circulating bacteria, compared to germfree controls. These results suggest that the L. acidophilus strain used here stimulates a nonspecific immune response and is a strong candidate to be used as a probiotic.
Key words

- Lactobacillus

- Macrophages

- Kupffer cells

- Probiotics 


\section{Introduction}

The adverse effect of toxic metabolites from the intestinal microbiota was first claimed by Elie Metchnickoff at the begining of this century. According to Gilliland (1), Metchnickoff postulated that the consumption of milk fermented with lactic acid bacteria could control this "intoxication" by regulating the number and types of microorganisms present in the intestinal tract. Since then, lactic acid bacteria, mainly those of the genus Lactobacillus, have been present in food and drugs for human and animal consumption. These formulations containing live microorganisms or microbial stimulants that have some beneficial influence on the maintenance of a balanced intestinal microbiota and on the improvement of the host immune system are called probiotics (2).

In order to be used as probiotics, microorganisms must have the following characteristics: 1) to be normal inhabitants of the host intestinal tract, 2) resist stressing conditions of the intestinal tract and establish in this environment, 3 ) exert beneficial effects on the host, 4) stay viable in food and drug formulations (3). Lactic acid bacteria have all these characteristics, are not enteropathogenic or enterotoxigenic and are known for their ability to suppress the growth of species of enteric bacteria in vitro (4-6). Although physiological conditions in vivo are vastly different from in vitro model systems used for most studies, the presence of lactic acid bacteria in the intestine is postulated to limit the growth, metabolism or survival of other enteric bacteria, which may in turn limit pathogenic or toxigenic effects (7-9). Many other biological effects have been attributed to lactic acid bacteria, such as bile salt deconjugation (10), induction of higher tolerance to lactose when given to lactoseintolerant subjects $(11,12)$, anticholesterolemic effects (13-15) and anticarcinogenic properties (16-18). The latter effect seems to be related to macrophage activity and recent studies have demonstrated that Lactobacillus and other lactic acid bacteria can increase the phagocytic capacity and enzymatic activity of mouse peritoneal cells (1923). Moreover, Sato (24) has demonstrated that intravenous injection and ingestion of $L$. case $i$ increase the survival of mice to infection with Listeria monocytogenes.

L. acidophilus UFV-H2b20 was isolated at the Universidade Federal de Viçosa, Minas Gerais, Brazil, from the feces of a newborn child, with the objective of isolating a new probiotic for human use in pathological states. The work described here was designed to investigate the capacity of this strain to survive and establish in the intestinal tract and affect the host phagocytic capacity. We found that L. acidophilus UFV-H2b20 passes through the intestinal tract of Swiss mice without suffering any damage, and colonizes germfree mice successfully. Mice receiving viable or heat-killed $L$. acidophilus UFVH2b20 were more efficient in clearing an enteropathogenic bacterium from the blood stream and had a higher number of Kupffer cells in the liver. These results demonstrate that $L$. acidophilus UFV-H2b20 is a candidate to be an effective probiotic.

\section{Material and Methods}

\section{Animals and microorganisms}

Swiss/NIH mice were maintained at the Gnotobiology Laboratory of the Department of Biochemistry and Immunology, Federal University of Minas Gerais, MG, Brazil, according to the procedures described by Pleasants (25) and were used shortly after weaning (21-23 days). Conventional animals of the same age and of both sexes were obtained from our colony. Lactobacillus acidophilus UFV-H2b20, a strain of human origin, was isolated at the Federal University of Viçosa, Minas Gerais, Brazil, and maintained at $-70^{\circ} \mathrm{C}$ in non-fat reconstituted dry milk containing $20 \%$ glycerol. The strain 
was grown in MRS broth (De Man, Rogosa \& Sharpe, Merck, São Paulo, Brazil) for $18 \mathrm{~h}$ at $37^{\circ} \mathrm{C}$ just before use. Escherichia coli $\mathrm{B}_{41}$ $\left(\mathrm{K}^{\circ}{ }^{+}, \mathrm{F} 41\right.$, kind gift from Dr. Moon, NADL, Ames, IA, USA) was maintained at $4^{\circ} \mathrm{C}$ on Lignières agar (Merck). Before use, cultures were grown overnight in BHI broth (Brain and Heart Infusion, Merck) at $37^{\circ} \mathrm{C}$.

\section{Monoassociation with $L$. acidophilus and treatment with killed organisms}

The activated culture of $L$. acidophilus UFV-H2b20 was centrifuged at $2000 \mathrm{~g}$ at $4^{\circ} \mathrm{C}$ and resuspended in phosphate-buffered saline (PBS) in order to obtain $10^{9}$ colonyforming units $(\mathrm{CFU}) / \mathrm{ml}$. One hundred microliters of this suspension was inoculated intragastrically into germfree mice. The success of monoassociation was checked by investigating the number of microorganisms per gram of feces and by determining the number of bacteria in several parts of the gastrointestinal tract. Heat-killed $L$. acidophilus UFV-H2b20 was obtained by heating a suspension containing $10^{9} \mathrm{CFU} / \mathrm{ml}$ of saline at $121^{\circ} \mathrm{C}$ for $15 \mathrm{~min}$ in a hospital-type autoclave. One hundred microliters of this suspension was inoculated daily intragastrically for 7 days. Control groups received the same amount of saline solution.

\section{Clearance of Escherichia coli $\mathbf{B}_{41}$}

Germfree Swiss mice were monoassociated with $L$. acidophilus UFV-H2b20 by single inoculation. After 7 days, mice were tested for their capacity to clear a Gramnegative bacterium injected systemically. An 18-h culture of E. coli $\mathrm{B}_{41}$ was centrifuged $(2000 \mathrm{~g})$ and resuspended in sterile saline at $10^{8} \mathrm{CFU} / \mathrm{ml}$. This number of bacteria was estimated by turbidity $(\lambda=550 \mathrm{~nm})$ and the absorbance was adjusted to 50 units of transmittance. Mice were injected with $0.2 \mathrm{ml}$ of this suspension into the tail vein after ether anesthesia. Blood samples were collected from the retro-orbital plexus of anesthetized animals immediately after injection of $E$. coli $\mathrm{B}_{41}$ (time 0 ) and at 15, 30, 60 and 90 min after injection. After the last blood collection, mice were sacrificed. Ten-fold serial dilutions of blood samples were plated and cultured on Petri dishes containing MacConkey medium (Merck). Dishes were incubated overnight at $37^{\circ} \mathrm{C}$ and colonies counted. Results are reported as percent CFU of the counts obtained for time 0 . Means were compared by the Student $t$-test.

\section{Clearance of colloidal carbon}

A 2:1 dilution of colloidal carbon (India ink, Pelikan, São Paulo, Brazil) in sterile PBS, pH 7.2, was injected into the tail vein of monoassociated and control mice. Twenty microliters of blood was collected from the retroorbital plexus at $0,5,10$ and $15 \mathrm{~min}$ after injection and hemolyzed in $4 \mathrm{ml} 0.1 \%$ $\mathrm{Na}_{2} \mathrm{CO}_{3}$ and absorbance was measured at $650 \mathrm{~nm}$. The results are reported as percent absorbance of the value obtained for time 0 (26).

\section{Macrophage ablation by silica injection}

In order to impair the phagocytic activity of macrophages, conventional Swiss mice were inoculated with $100 \mu \mathrm{l}$ of a suspension containing $4 \mathrm{mg}$ of silica dust (particle size $<5 \mu \mathrm{m}$ ) in PBS. After $4 \mathrm{~h}$, the animals were injected with either $E$. coli $\mathrm{B}_{41}$ or colloidal carbon as described above.

\section{Histological analysis of organs and small intestine}

Tissues (small intestine, liver and spleen) were fixed in $10 \%$ formalin in PBS, embedded in paraffin, cut into 5 - $\mu \mathrm{m}$ thick sections and stained with hematoxylin-eosin. Preparations were coded and examined by one individual who had no access to the codes. The morphometry for crypts and villi was 
Figure 1 - Clearance of E. coli $\mathrm{B}_{41}$ in germfree (squares) and conventional (circles) Swiss mice. E. coli $B_{41}$ was injected into the tail vein and blood samples were taken from the retro-orbital plexus at the time of injection and 15, 30, 60 and $90 \mathrm{~min}$ after injection. Ten-fold serial dilutions of blood were plated and cultured on Petri dishes containing MacConkey medium. Dishes were incubated overnight at $37^{\circ} \mathrm{C}$ and colonies counted. The results are reported as percent viable cells per $\mathrm{ml}$ blood in relation to time 0 . Each point is the mean for 5 mice of one representative experiment of three performed. Vertical bars indicate standard deviation of the means. *P $\leq 0.05$ compared to conventional mice (Student t-test).

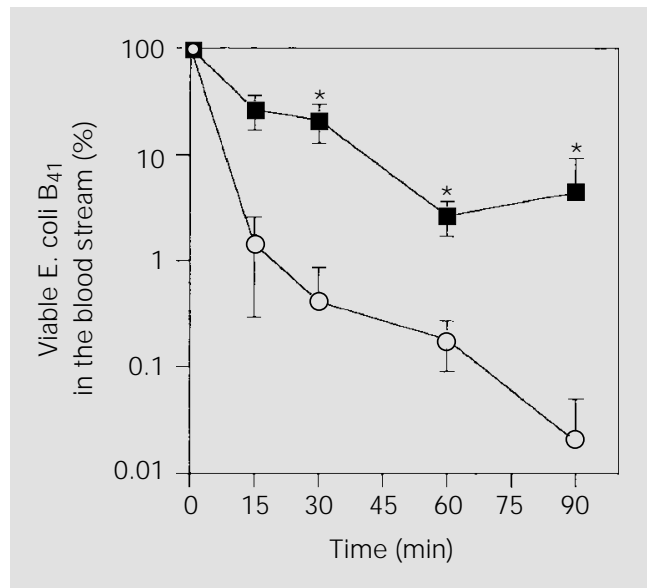

performed using an image analysis program (KS 300-Zeiss) running on an IBM 486 computer. Six vertically arranged villi were analyzed for each animal.

\section{Results}

In order to determine the effect of $L$. acidophilus on the capacity of mice to clear a systemic infection, conventional Swiss mice were inoculated daily intragastrically with $0.1 \mathrm{ml}$ of a suspension containing $10^{9} \mathrm{CFU} /$ $\mathrm{ml}$ of $L$. acidophilus UFV-H2b20 for 7 days and their capacity to clear $E$. coli $\mathrm{B}_{41}$ from the blood stream was determined. Both the control group (treated with saline solution) and the Lactobacillus-treated group showed efficient clearance within $90 \mathrm{~min}$, with the levels of bacteria in the bloodstream being below the detection limit (data not shown). Similar results were observed when colloidal carbon was used (data not shown). In both experimental models, the control group showed a very efficient clearance capacity, therefore masking the effect of ingestion of Lactobacillus. Thus, these models were not appropriate for demonstrating the effect of Lactobacillus on host clearance capacity.

Macrophages of germfree animals have a deficient phagocytic power (27). In addition, the lack of normal microflora makes these animals good models to test the ability of a microorganism to survive in the gastrointes- tinal tract and to determine the effect of association with a single microorganism on the system. Monoassociation of germfree mice with $L$. acidophilus UFV-H2b20 was successfully obtained in the present study. The high level of L. acidophilus UFV-H2b20 in feces 7 days after inoculation of a single dose of the bacterium (up to $10^{10} \mathrm{CFU} / \mathrm{g}$ of feces) suggests that this microorganism is capable of passing through the intestinal tract without being damaged by intestinal secretions or peristaltism, and of colonizing the gut. In fact, up to $10^{8} \mathrm{CFU} / \mathrm{g}$ of organ were found even in the stomach, where lactobacilli are exposed to very low $\mathrm{pH}$ (data not shown). We then proceeded to compare the kinetics of $E$. coli $\mathrm{B}_{41}$ clearance from the bloodstream in conventional and germfree mice. Germfree animals had an impaired clearance capacity when compared to their conventional counterparts (Figure 1). Thus, while conventional animals had reduced the number of bacteria by a factor of five $\log$ cycles within $90 \mathrm{~min}$, germfree mice brought the number of bacteria down only one $\log$ cycle. Interestingly, treatment of conventional mice with silica dust $4 \mathrm{~h}$ before the clearance test, although impairing clearance of E. coli $\mathrm{B}_{41}$ (Figure $2 \mathrm{~A}$ ), did not reduce the clearance to the low level observed in germfree animals. Silica dust also diminished the clearance of colloidal carbon (Figure 2B). Monoassociation of germfree mice with $L$. acidophilus UFV-H2b20 for 7 days improved the capacity of these animals to clear E. coli $\mathrm{B}_{41}$ injected systemically (Figure 3 ). In fact, the clearance capacity of monoassociated mice was quite comparable to that of conventional mice (Figures 1 and 2A). Even more interestingly, germfree mice who received a high dose $\left(10^{8} \mathrm{CFU}\right)$ of heat-killed L. acidophilus UFV-H2b20 daily for one week also showed improved clearance when compared to untreated germfree mice (Figure 4). These results suggest that there may be a thermostable, systemic stimulating factor in Lactobacillus cells. 
Hepatosplenomegaly could be an undesirable side effect of association with $L$. acidophilus UFV-H2b20 which would result in an improved clearance of bacteria from the bloodstream. However, there was no difference in the organ weight/body weight ratio in the tested groups (data not shown). Nevertheless, the number of Kupffer cells in the livers of monoassociated mice was higher than in germfree controls (Figure 5). These results suggest that Kupffer cells might be responsible for the improved clearance in monoassociated mice.

Morphometric analysis of the small intestine showed that monoassociation with $L$. acidophilus UFV-H2b20 significantly reduced the height of the villi in the majority of animals tested (Figure 6). There was no variation in the number of intraepithelial leucocytes in monoassociated animals when compared with germfree controls. This number was three-fold higher in conventional animals than in germfree controls (data not shown).

One mechanism that could explain the systemic effect of ingestion of L. acidophilus would be the translocation of these microorganisms to mesenteric lymph nodes, where they could be taken up by macrophages or dendritic cells which, in turn, could release pro-inflammatory and phagocyte-activating cytokines. Mesenteric lymph nodes from mice associated for 7 days with $L$. acidophilus were mostly positive for the bacterium, which, however, was present in variable numbers (between zero and $10^{5} \mathrm{CFU} / \mathrm{g}$ organ).

\section{Discussion}

The search for microorganisms to be used as probiotics has gained a significant impulse in the last few years (2). Increasing emphasis has been placed on the therapeutic and nutritional effect of foods fermented with lactic acid bacteria, mainly lactobacilli and bifidobacteria (17). For this reason, ef-

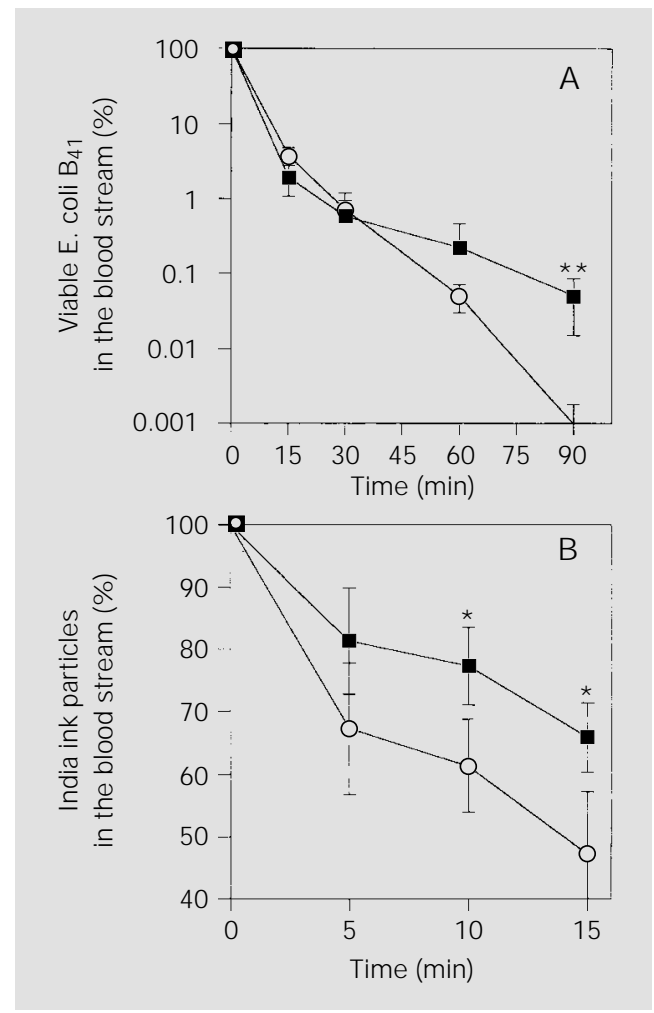

Figure 2 - Effect of treatment with silica on the clearance of $E$. coli $B_{41}(A)$ and India ink (B). E. coli $B_{41}$ or India ink suspension was injected into the tail vein of conventional (circles) or silicatreated conventional (squares) mice and blood samples were taken from the retro-orbital plexus at the time of injection and 15, 30, 60 and 90 min after injection and treated as described in Material and Methods. The results are reported as percent viable cells per $\mathrm{ml}$ blood determined as described in the legend to Figure 1 (A) or as absorbance $(\lambda=650 \mathrm{~nm})(B)$ in relation to time 0 . Each point is the mean for 5 mice of one representative experiment of two performed. Vertical bars indicate standard deviation of the means. *P $\leq 0.05$, **P $\leq 0.01$ compared to conventional mice (Student ttest).

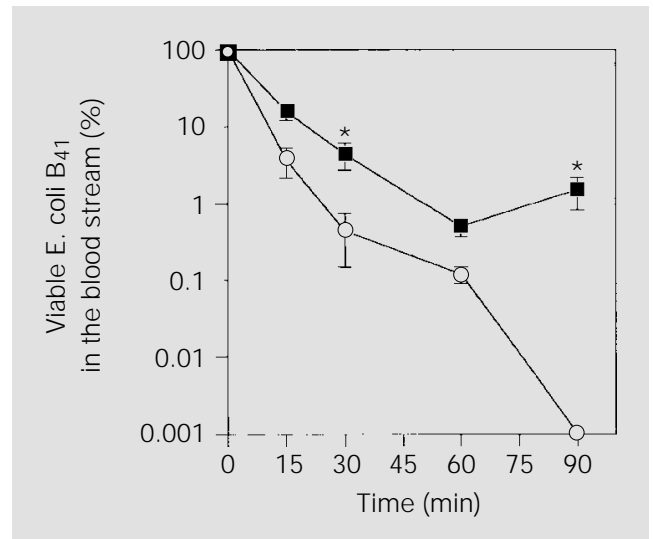

forts have been made to isolate strains of lactobacilli that can become established in the host intestinal tract and effectively promote their beneficial effects.

The strain studied here, L. acidophilus UFV-H2b20, is a strong candidate for a probiotic since it survived the conditions of the intestinal tract in germfree mice in vivo. These data are in accordance with in vitro
Figure 3 - Clearance of E. coli $B_{41}$ in germfree (squares) and $L$. acidophilus UFV-H2b20-monoassociated (circles) mice. E. coli $\mathrm{B}_{41}$ was injected into the tail vein and blood samples were taken from the retro-orbital plexus at the time of injection and 15, 30, 60 and 90 min after injection. Ten-fold serial dilutions of blood were plated and cultured on Petri dishes containing MacConkey medium. Dishes were incubated overnight at $37^{\circ} \mathrm{C}$ and colonies counted. The results are reported as percent viable cells per $\mathrm{ml}$ blood in relation to time 0 . Each point is the mean for 5 mice of one representative experiment of three performed. Vertical bars indicate standard deviation of the means. * $\mathrm{P} \leq 0.05$ compared to monoassociated mice (Student t-test). 


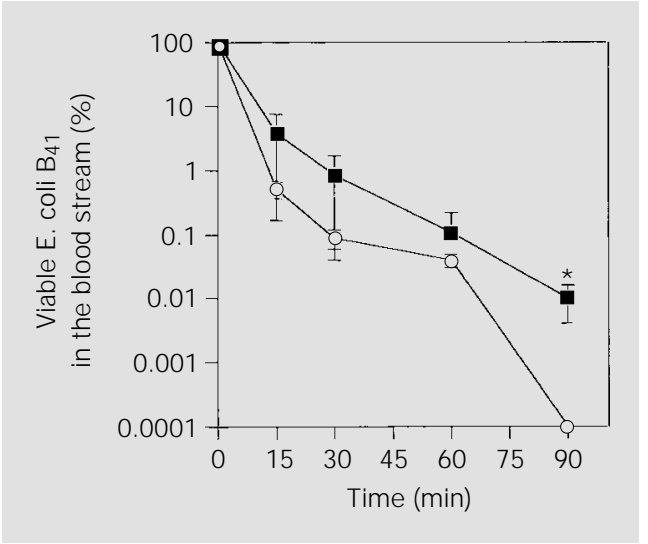

Figure 4 - Clearance of $\mathrm{E}$. coli $\mathrm{B}_{41}$ in germfree (squares) or heat-killed L. acidophilus UFV-H2b20-treated Swiss mice (circles). Germfree mice received $10^{8}$ cells of $\mathrm{L}$. acidophilus intragastrically daily for 7 days. E. coli $B_{41}$ was injected into the tail vein and blood samples were taken from the retro-orbital plexus at $0,15,30,60$ and 90 min after injection. Ten-fold serial dilutions of blood were plated and cultured on Petri dishes containing MacConkey medium. Dishes were incubated ovemight at $37^{\circ} \mathrm{C}$ and colonies counted. The results are reported as percent viable cells per $\mathrm{ml}$ blood in relation to time 0 . Each point is the average of data for 5 mice from one representative experiment of two performed. Vertical bars indicate standard deviation of the means. $* \mathrm{P} \leq 0.05$ compared to monoassociated mice (Student $\mathrm{t}$ test).
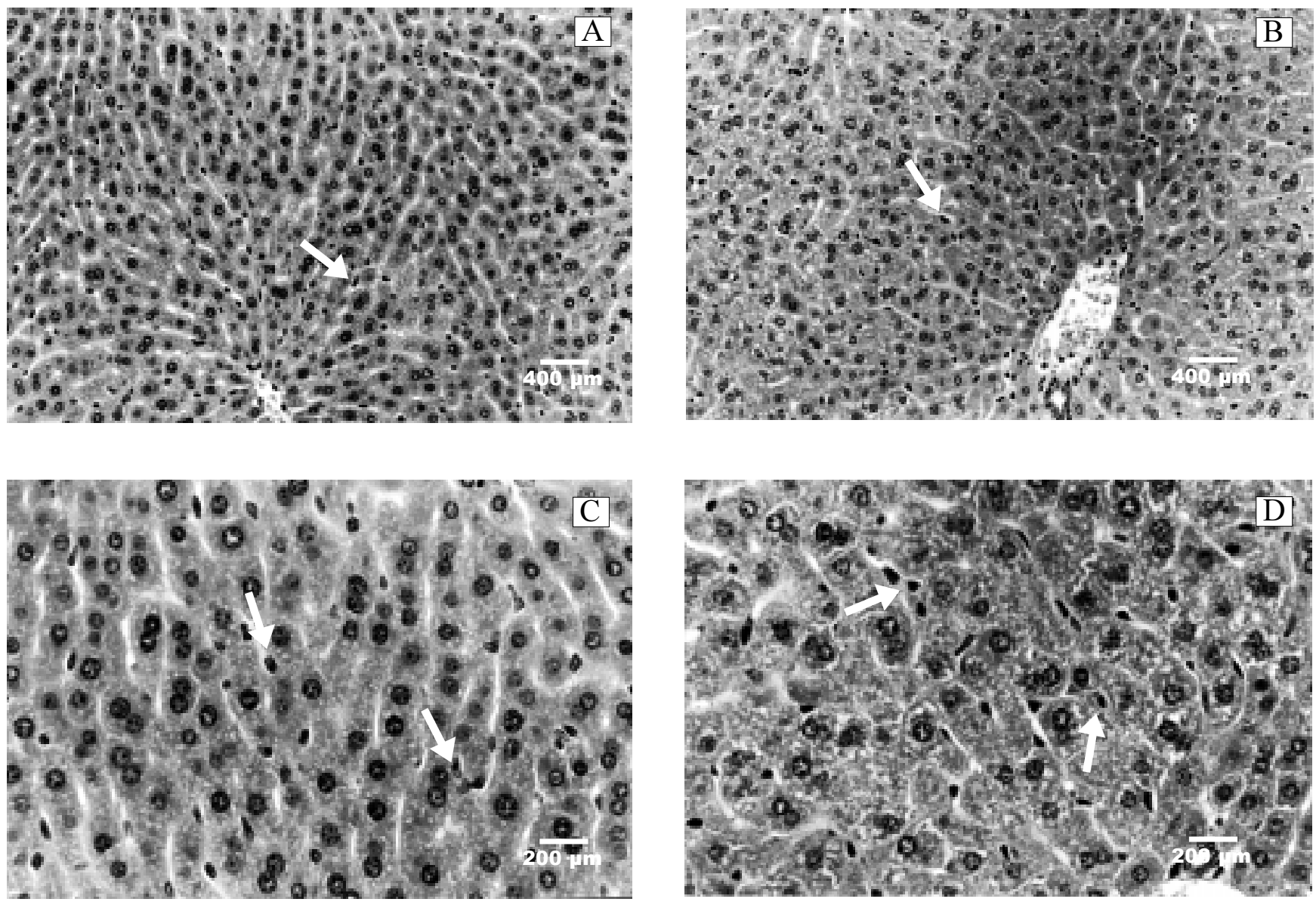

Figure 5 - Liver histology of germfree $(A, C)$ and L. acidophilus UFV-H2b20-monoassociated Swiss mice (B,D). Note the increase in the number of Kupffer cells (arrows) in liver of monoassociated mice. Stained histological samples of liver were examined using a computerized image analyzer system composed of a standard binocular microscope (Zeiss) attached to an IBM compatible computer using the KS 300 program to count cells. Hepatocytes and Kupffer cells were counted in 5 fields ( $53334.4 \mu \mathrm{m}^{2} /$ field) for each sample. Germfree animals had $107.5 \pm 16.5$ hepatocytes/field, 21.5 $\pm 4.9 \mathrm{Kupffer}$ cells/field and a ratio of $0.20 \mathrm{Kupffer}$ cells/hepatocyte. Monoassociated mice had $86.3 \pm 17.6$ hepatocytes/field, $36.0 \pm 5.57 \mathrm{Kupffer}$ cells/ field and a Kupffer cell/hepatocyte ratio of 0.42. Hematoxylin-eosin staining. Magnification bars: A and B, $400 \mu \mathrm{m} ; \mathrm{C}$ and D, $200 \mu \mathrm{m}$. 
tests of resistance of $L$. acidophilus UFV$\mathrm{H} 2 \mathrm{~b} 20$ to intestinal conditions (28). According to Gilliland (1), one of the most important characteristics of a candidate for a probiotic is its capacity to resist the stressing conditions in the gut. The presence of $L$. acidophilus UFV-H2b20 in the stomach of germfree mice is not surprising since mice normally present lactobacilli in the stomach (29). However, it is interesting to note that the Lactobacillus strain used in our studies is of human origin, and was not necessarily expected to survive at high concentrations in the stomach and intestine.

The present results suggest that this strain is capable of stimulating the phagocytic capacity of the host macrophages. The same effect has been shown by other authors for another species of Lactobacillus. Kato et al. (19) demonstrated that intraperitoneal injection of $L$. case $i$ improved the cytotoxic activity of phagocytes against tumoral cells. Perdigon et al. (20) showed the increased phagocytic capacity of mice who received high doses of L. casei. However, the latter authors tested the phagocytic capacity by measuring the clearance of an inert particle from the host bloodstream (colloidal carbon). We did not observe this effect of our $L$. acidophilus strain using the same system. Moreover, we demonstrated that there was no effect of $L$. acidophilus on the host phagocytic capacity by measuring the clearance of a complex agent (a Gram-negative bacterium) which could more faithfully reproduce a pathological situation. That Perdigon et al. (20) found an effect on the clearance of particles by conventional mice that we did not observe may be explained by the fact that, as demonstrated by that group, different strains of lactobacilli differ as to their effect in conventional animals. It is also possible that in our study L. acidophilus $\mathrm{H} 2 \mathrm{~b} 20$ was not present in high enough number in conventional animals, since the normal microbiota would be an efficient barrier against the colonization by foreign organisms in a

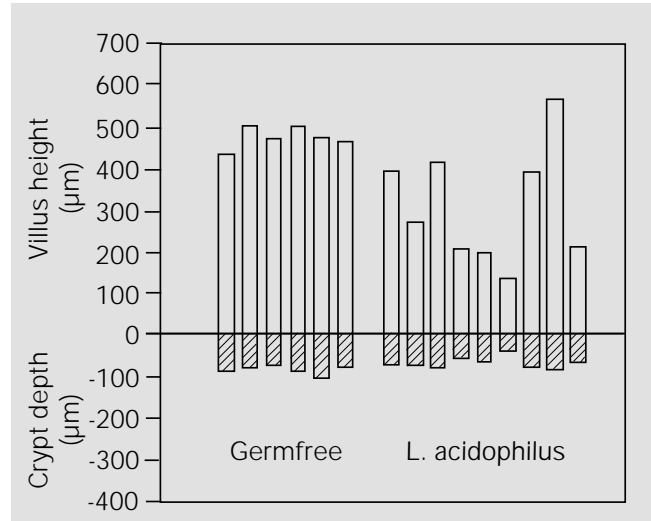

healthy animal (9). However, we demonstrated here that an effect was observed when the animal does have an impaired clearance capacity. Moreover, our preliminary observations suggest that, although immunosuppressed conventional mice show a diminished clearance capacity, treatment of these mice with $L$. acidophilus $\mathrm{H} 2 \mathrm{~b} 20$ improved clearance (data not shown).

Germfree mice are good as models to overcome the barrier effects of the normal microbiota and to demonstrate the effects of a single species of microorganism on the host (30). The clearance of $E$. coli from the bloodstream of germfree mice was inefficient when compared with that observed for monoassociated and conventional animals (Figure 1). These results confirm the putative involvement of the microbiota in the systemic stimulation of the immune response (31). L. acidophilus-monoassociated mice showed as efficient a clearance as conventional mice (Figures 1 and 3), which means that this strain of Lactobacillus per se has the capacity of stimulating a systemic response, as was demonstrated for other lactic bacteria $(19,20,32)$. More interesting was the fact that heat-killed L. acidophilus also stimulates the clearance capacity (Figure 4), suggesting that a thermostable stimulating factor is present. This observation is important for the formulation of a probiotic and speaks for the stability of preparations made with the particular strain we used in the present
Figure 6 - Small intestine morphometry of germfree and L. acidophilus UFV-H2b20-monoassociated mice. After 7 days of monoassociation, mice were sacrificed and the small intestine was collected in phosphatebuffered formalin. Each bar represents one animal. Villus height was significantly smaller in monoassociated animals (Student t-test, $\mathrm{P}=0.013$ ). Crypt depth was also significantly smaller in monoassociated mice (Student t-test, $\mathrm{P}=0.03$ ). 
study. Accordingly, Chauvière et al. (29) showed the effect of heat-killed L. acidophilus on inhibition of enterotoxigenic E. coli adhesion onto the brush border of the polarized epithelial human intestinal cells in culture. Furthermore, Coconnier et al. (33) showed the same effect of heat-killed $L$. acidophilus against Salmonella typhimurium, enteropathogenic E. coli, Yersinia pseudotuberculosis and Listeria monocytogenes. Several other investigators have demonstrated that components of Gram-positive bacterial membranes could stimulate nonspecific host resistance against $E$. coli (34), produce acute joint inflammation (35) and stimulate synthesis of TNF- $\alpha$ and IL- 6 by human monocytes (36). Taken together, these data suggest that pro-inflammatory and phagocyteactivating factors may be the mediators triggered by Gram-positive probiotics, producing a systemic effect which is independent of the more obvious local effects of inhibition of adhesion, inhibition of growth or competition for nutrients in the gut.

The role of Kupffer cells in the clearance of some pathogens was studied by Friedman and Moon (37) who demonstrated that destruction of Kupffer cells by silica treatment enhanced susceptibility to infection with Salmonella typhimurium in mice. The same laboratory (38) also demonstrated that the bactericidal effect of Kupffer cells depends on complement activation. Interestingly, Conlan and North (39) showed that Kupffer cells are involved in different ways in early defense strategies against three different in- tracellular bacteria. The lower number of Kupffer cells in germfree animals than in conventional animals has been previously shown (40). In this study, we observed an increase in the number of Kupffer cells in livers of monoassociated mice (Figure 5) which could explain the improved clearance capacity of these mice. This increase brought the number of Kupffer cells in monoassociated mice to values similar to the ones found in conventional mice. Furthermore, we demonstrated that silica-treated mice had less $E$. coli and colloidal carbon clearance than normal conventional animals (Figure 2).

Finally, the intestinal wall of monoassociated mice was altered. Monoassociated mice showed smaller villi (Figure 6), which could increase translocation of bacteria and cause the exposure of distant lymphoid organs to the probiotic. Accordingly, viable lactobacilli were detected in the mesenteric lymph nodes in several individuals. The present results demonstrate that lactic bacteria or one of their constituents can be in direct contact with the host systemic immune milieu and stimulate the host natural immune response. Other experiments are being performed in our laboratory in order to elucidate the mechanism of action of these bacteria.

\section{Acknowledgments}

The authors wish to thank Ronilda Maria de Paula, Maria Helena Alves de Oliveira and Antônio M. Vaz for the animal care.

\section{References}

1. Gilliland SE (1989). Acidophilus milk products: A review of potential benefits to consumers. J ournal of Dairy Science, 72 : 2483-2494.

2. Fuller R (1992). History and development of probiotics. In: Fuller R (Editor), Probiotics: The Scientific Basis. Chapman \& Hall, London.

3. Shahani KM \& Ayebo AD (1980). Role of dietary lactobacilli in gastrointestinal microecology. American J ournal of Clini- cal Nutrition, 33: 2448-2457.

4. Gilliland SE (1979). Beneficial interrelationships between certain microorganisms and humans: candidate microorganisms for use as dietary adjuncts. J ournal of Food Protection, 42: 164-167.

5. Fernandes CF, Shahani KM \& Amer MA (1987). Therapeutic role of dietary lactobacilli and lactobacillic fermented dairy products. FEMS Microbiology Reviews, 46: 343-356.
6. Shahani KM \& Chandan RC (1979). Nutritional and healthful aspects of cultured and culture-containing dairy foods. J ournal of Dairy Science, 62: 1685-1694.

7. Nader de Macias ME, Apella MC, Romero NC, González SN \& Oliver G (1992). Inhibition of Shigella sonnei by Lactobacillus casei and Lactobacillus acidophilus. J ournal of Applied Bacteriology, 73: 407-411.

8. De Simone C, Tzantzoglou S, Baldinelli L, Di Fabio S, Bianchi-Salvadori B, J irillo E \& 
Vesely R (1988). Enhancement of host resistance against Salmonella typhimurium infection by a diet supplemented with yogurt. Immunopharmacology and Immunotoxicology, 10: 399-415.

9. Bernet MF, Brassart D, Neeser JR \& Servin AL (1994). Lactobacillus acidophilus LA1 binds to cultured human intestinal cell lines and inhibits cell attachment and cell invasion by enterovirulent bacteria. Gut, 35: 483-489.

10. Gilliland SE \& Speck ML (1977). Deconjugation of bile acids by intestinal lactobacilli. Applied and Environmental Microbiology, 33: 15-18.

11. Kilara A \& Shahani KM (1976). Lactase activity of cultured and acidified dairy products. J ournal of Dairy Science, 59: 2031-2035.

12. Kim HS \& Gilliland SE (1983). Lactobacillus acidophilus as a dietary adjunct for milk to aid lactose digestion in humans. J ournal of Dairy Science, 66: 959-966.

13. Gilliland SE, Nelson CR \& Maxwell C (1985). Assimilation of cholesterol by Lactobacillus acidophilus. Applied and Environmental Microbiology, 49: 377-381.

14. Klaver FAM \& Meer R (1993). The assumed assimilation of cholesterol by lactobacilli and Bifidobacterium bifidum is due to their bile salt-deconjugating activity. Applied and Environmental Microbiology, 59: 1120-1124.

15. Mital BK \& Garg SK (1995). Anticarcinogenic, hypocholesterolemic, and antagonistic activities of Lactobacillus acidophilus. Critical Reviews in Microbiology, 21: 175-214.

16. Shahani KM, Friend BA \& Bailey PJ (1983). Antitumor activity of fermented colostrum and milk. J ournal of Food Protection, 46: 385-386.

17. Marteau $P$, Pochart $P$, Flourié $B$, Pellier $P$, Santos L, Desjeux J F \& Rambaud J C (1990). Effect of chronic ingestion of a fermented dairy product containing Lactobacillus acidophilus and Bifidobacterium bifidum on metabolic activities of the coIonic flora in humans. American J oumal of Clinical Nutrition, 52: 685-688.

18. McConnell MA \& Tannock GW (1993). A note on lactobacilli and B-glucuronidase activity in the intestinal contents of mice. J ournal of Applied Bacteriology, 74: 649651.

19. Kato I, Yokokura T \& Mutai M (1983). Macrophage activation by Lactobacillus casei in mice. Microbiology and Immunol- ogy, 27: 611-618.

20. Perdigon G, Nader de Macias ME, Alvarez S, Oliver G \& Ruiz Holgado AAP (1986). Effect of perorally administered lactobacilli on macrophage activation in mice. Infection and Immunity, 53: 404-410.

21. Perdigon G, Nader de Macias ME, Alvarez S, Oliver G \& Ruiz Holgado AAP (1986). Lactobacilli administered orally induce release of enzymes from peritoneal macrophages in mice. Milchwissenschaft, 41: 344-348.

22. Perdigon $G$, Nader de Macias ME, Alvarez S, Oliver G \& Ruiz Holgado AAP (1987). Enhancement of immune response in mice fed with Streptococcus thermophilus and Lactobacillus acidophilus. J ournal of Dairy Science, 70: 919-926.

23. Perdigon $G$, Nader de Macias ME, Alvarez S, Oliver G \& Ruiz Holgado AAP (1988). Systemic augmentation of the immune response in mice by feeding fermented milks with Lactobacillus casei and Lactobacillus acidophilus. Immunology, 63: 1723.

24. Sato K (1984). Enhancement of host resistance against Listeria infection by Lactobacillus casei: role of macrophages. Infection and Immunity, 44: 445-451.

25. Pleasants R (1974). Gnotobiotics. In: Melby J R \& Altman NH (Editors), Handbook of Laboratory Animal Science. CRC Press, Cleveland.

26. Kierszenbaum F, Knecht E, Budzko DB \& Pizzimenti MC (1974). Phagocytosis: a defense mechanism against infection with Trypanosoma cruzi. J ournal of Immunology, 112: 1839-1844.

27. Podoprigora G (1990). Phagocytic activity of the mononuclear phagocyte system in gnotobiotic animals under conditions of aging and experimental burn injury. $\mathrm{Mi}$ croecology and Therapy, 20: 203-211.

28. Agostinho SMM (1988). Comportamento de $\mathrm{L}$. acidophilus H2b2O sob condições do trato digestivo in vitro e efeito de métodos de preservação em sua atividade. Master's thesis, Universidade Federal de Viçosa, Viçosa.

29. Chauvière $G$, Coconnier $M H$, Kerneis $S$, Darfeuille-Michaud A, J oly B \& Servin AL (1992). Competitive exclusion of diarrheagenic Escherichia coli (ETEC) from human enterocyte-like Caco-2 cells by heat-killed Lactobacillus. FEMS Microbiology Letters, 91: 213-218.

30. Gordon HA \& Pesti L (1971). The gnotobiotic animal as a tool in the study of host microbial relationships. Bacteriological Reviews, 35: 390-429.

31. Famularo G, Moretti S, Marcellini $S \& D e$ Simone $S$ (1997). Stimulation of immunity by probiotics. In: Fuller R (Editor), Probiotics 2: Applications and Practical Aspects. Chapman \& Hall, London.

32. Perdigon G \& Alvarez S (1992). Probiotics and the immune state. In: Fuller R (Editor), Probiotics: the Scientific Basis. Chapman \& Hall, London.

33. Coconnier $M H$, Bernet MF, Kemeis $S$, Chauvière G, Fourniat J \& Servin AL (1993). Inhibition of adhesion of enteroinvasive pathogens to human intestinal Caco- 2 cells by Lactobacillus acidophilus strain LB decreases bacterial invasion. FEMS Microbiology Letters, 110: 299306.

34. Matsumoto $K$, Ogawa $H$, Nagase $O$, Kusama T \& Azuma I (1981). Stimulation of nonspecific host resistance to infection induced by muramyldipeptides. Microbiology and Immunology, 25: 1047-1058.

35. Koga T, Kakimoto K, Hirofuji T, Kotani S \& Sumiyoshi A (1986). Muramyl dipeptide induces acute joint inflammation in the mouse. Microbiology and Immunology, 30: 717-723.

36. Heumann D, Barras C, Severin A, Glauser MP \& Tomasz A (1994). Gram-positive cell walls stimulate synthesis of tumor necrosis factor alpha and interleucin- 6 by human monocytes. Infection and Immunity, 62: 2715-2721.

37. Friedman RL \& Moon RJ (1977). Hepatic clearance of Salmonella typhimurium in silica-treated mice. Infection and Immunity, 16: 1005-1012.

38. Friedman RL \& Moon RJ (1980). Role of Kupffer cells, complement, and specific antibody in the bacterial activities of perfused livers. Infection and Immunity, 29: 152-157.

39. Conlan J W \& North RJ (1992). Early pathogenesis of infection in the liver with the facultative intracellular bacteria Listeria monocytogenes, Francisella tularensis, and Salmonella typhimurium involves lysis of infected hepatocytes by leukocytes. Infection and Immunity, 60: 5164-5171.

40. Podoprigora GI \& Zaitsev TI (1979). Morphological and functional status of elements of the reticuloendothelial system of gnotobiotic animals. Folia Microbiologica, 24: 55-56. 


\section{David Rockefeller Center for Latin American Studies Harvard University}

\author{
"Lemann Visiting Scholars and Fellows \\ Program" Brasil
}

The David Rockefeller Center for Latin American Studies, Harvard University, invites candidates for its "Visiting Scholars and Fellows Program". The "Visiting Scholars and Fellows Program" is a program for academic and non-academic professionals interested in developing research for a determined period of time (one or two academic semesters) while residing at Harvard University. The selection of professionals is made by an examination.

With the support of Mr. Jorge Paulo Lemann, the Center recently created the "Lemann Visiting Fellowship". This is a fellowship for a professional for the above mentioned program whose research project has Brazil as the study objective. This fellowship is awarded once each academic year (September-June) and covers the administrative expenses of the Center and airline tickets. The professional will also receive financial assistance of US\$15,000 (fifteen thousand American dollars, subject to income tax), regardless of the number of semesters for which he is accepted.

Candidates must include, in English:

- Curriculum vitae;

- One page explaining why the candidate wishes to study at Harvard;

- Three or four pages describing the proposed research project;

- Two letters of reference from persons who can prove the qualifications of the candidate and the importance of the proposed project.

For additional information, contact:

Visiting Scholars and Fellows Program Coordinator David Rockefeller Center for Latin American Studies Harvard University

61 Kirkland Street

Cambridge, MA 02138 USA

Tel: (617) 495-3366 Fax: (617) 496-2802

e-mail:drclas@fas.harvard.edu

Web site: http://www.fas.harvard.edu/ drclas

\section{Post-doctorate fellowship in Germany Alexander Von Humboldt Foundation}

The Alexander Von Humboldt Foundation, which exists more than 130 years and whose actual structure was established a few years after WWII (1953), is offering fellowships for post-doctorate study and for specialized research projects in all areas of knowledge. There are 500 fellowships annually, distributed without limitation of nationality, and 150 fellowships (Feodor Lynen Research Fellowships), only for German researchers and professors, to work as invited researchers of ex-fellows of all nationalities and their Universities. The Alexander Von Humboldt Foundation Fellowships are open to all professors who meet the above-mentioned requisites and who are less than 40 years of age. There is also one specialized fellowship for candidates between 40 and 45 years of age. These fellowships are for 6 to 24 months, receiving 3400 to 4200 German marks monthly.

\author{
Interested candidates should contact: \\ Alexander Von Humboldt-Stiftung \\ Jean Paul Strasse 12 \\ D-53173 BONN (Germany) \\ Telefax: 0049-228-833-199 \\ Internet: http://www.avh.de
}

Ex-fellows of the Foundation are represented in Brazil by:

"Clube Humboldt do Brasil"

Av. Brig. Faria Lima, 1572 - $7^{\circ}$ andar, sala 705

01463-900 São Paulo, SP

President Prof. Dr. Bruno Konig Junior

Department of Anatomy, ICB, USP, São Paulo, Brasil

Tel: (011)818-7258 